\title{
The Middle-Class Entrepreneurial Elite in Šibenik and Split $\left(15^{\text {th }} \text { Century }\right)^{* * *}$
}

The paper explores the entrepreneurial elite of late medieval Šibenik and Split, based on the examples of prominent businessmen in the historical records preserved in the notarial records of the two cities.

Keywords: Šibenik, Split, entrepreneurship, Late Middle Ages, notarial records, Indricus de Indrico, Lovro Goniribić, Lapi, son of Zanobi, Andrea Alessi, Antun Hmelić

\section{Introduction}

The fifteenth century was in many ways a century of change in Dalmatian medieval history. Between 1409 and 1420, almost all Dalmatian communes acknowledged the rule of the Venetian Republic, which resulted in the integration of the entire northern and eastern Adriatic coast into a single political, territorial, and administrative system. This brought about a whole series of changes in the previously autonomous communes: urban, ethnic, and linguistic, and also social and economic changes examined in this paper. Even though the Venetian economic policy of the $15^{\text {th }}$ century hindered the development of certain economic activities in Dalmatia in order to promote Venetian interests, it also created new business

\footnotetext{
* Tonija Andrić, Department for History, Faculty of Humanities and Social Sciences, University of Split, Poljička 35, 21000 Split, Croatia, E-mail: tonija@ffst.hr

** Ante Birin, Croatian Institute of History, Opatička 10, 10000 Zagreb, Croatia, E-mail: ante.birin@ gmail.com

**** This research was conducted within the framework of the project URBES funded by the Croatian Science Foundation under no. IP-2014-09-7235.
} 
opportunities and encouraged fresh entrepreneurial ideas and projects. Above all, it opened up a new, much wider market than the one where Dalmatian entrepreneurs had been able to place their products and services previously, allowing numerous Schiavoni to, for example, bring to Venice Dalmatian agricultural produce on a daily basis, carefully selected to suit the sophisticated taste of the Venetian elite. In addition to wealthy landowners and farmers, large traders and businessoriented artisans also profited from the new economic circumstances and managed to successfully diversify their activities, extend the reach of their business, and boost their profits. Innovative Dalmatian entrepreneurs were increasingly investing in the profitable maritime trade, loan business, and trading companies, all the while skilfully using the accumulated surplus capital as a symbol of their status and their social standing. This layer of entrepreneurial elite grew so strong over time that it emerged as an intermediate social class, even though the boundaries imposed on the middle-class commoners were far more flexible than those imposed on the patricians, a layer that remained unattainable to those outside the circle. Namely, since the residents of medieval communes based their social reputation and status on personal pervasiveness, entrepreneurial abilities, and acquired wealth, it was the material status of each individual that determined his position on the social stratification scale.

Based on the preserved documents in the notarial records of Šibenik and Split, this paper focuses on the entrepreneurial elite in Dalmatia, whose members secured their own social and economic advancement by exploiting the business opportunities of the Venetian economic system. The selected examples illustrate the comprehensiveness of their business, the technology behind their economic activity, and various ways in which certain entrepreneurs accumulated substantial material wealth, which, in turn, earned them an unrivalled social reputation and a prominent place within the social elite of their communes.

\section{The entrepreneurial elite of late medieval Šibenik}

We shall first take a look at an individual whose capability and skill made him stand out among the entrepreneurial middle-class elite of late medieval Šibenik - Ser Indricus de Indrico (Indricus de Indrico, Indricus de Indricis), a newcomer from Venice. Ser Indricus, who was appointed public notary by the imperial authority (publicus imperiali auctoritate notarius), arrived in Šibenik sometime before 1430 and worked among the numerous administrative and clerical staff who settled here after the reestablishment of the Venetian rule in Dalmatia at the beginning of the $15^{\text {th }}$ century. ${ }^{1}$ During the first half of the 1430 s, Ser Indricus

\footnotetext{
1 The oldest known document prepared by Ser Indricus in his official capacity as Šibenik's notary mentioned in a later document, is dated March 16, 1430 - Croatia (hereafter: HR) - State Archive in Zadar (hereafter: SAZd), Officials of Šibenik Collection (hereafter: 30), box 11/5, fol. 60'.
} 
mainly devoted himself to his office, while at the same time serving as a judge and a chancellor of the Šibenik municipality. ${ }^{2}$ His scantily preserved notarial records, which consist of only thirty-eight documents dating from April 1431 to October 1434, originate from that first period. ${ }^{3}$ Although, in all likelihood, he initially did not intend to stay in Šibenik for good, which is why during the first ten years he did not purchase any real estate (and did not own a house), a combination of circumstances ultimately resulted in his permanent residence.

By the second half of the 1430s, Ser Indricus had already abandoned his profession, including the posts he held in the municipal administration, and dedicated himself to entrepreneurial activity. ${ }^{4}$ His breakthrough to the very top of Šibenik's social elite was, however, not only a result of his exceptional abilities, both professional and entrepreneurial, but also of his marriage to Jelena, daughter of Ser Stjepan Tišković, which took place sometime before 1442, when Indricus is first mentioned as Stjepan's son-in-law. ${ }^{5}$ Judging by the sources, Ser Indricus soon acquired the status of a citizen, the capacity in which he is first mentioned in $1446 .^{6}$

The business activity of Ser Indricus can be traced back to the second half of the 1430 s and is particularly well documented during the 1440 s. When it comes to real estate, it should be pointed out that Ser Indricus - permitted by his father-inlaw to use one of his houses in the neighbourhood of St Gregory ${ }^{7}$ - purchased his own house in the neighbourhood of All Saints, located in the very centre of the city, sometime before $1446 .{ }^{8}$ Apart from the house, at one point he also acquired (either by purchase or as dowry) a garden located outside the Outer Gate (extra portonum exteriorem). ${ }^{9}$

\footnotetext{
2 ... publicus imperiali auctoritate notarius, iudex oridinarius ac cancellarius communis Sibenici. Josip Barbarić, Josip Kolanović, Šibenski diplomatarij [Šibenik’s diplomata] (Šibenik: Muzej grada Šibenika, 1986), doc. 57, p. 136; doc. 103, pp. 244-247; doc. 104, pp. 248-249.

3 Ante Birin, "Spisi šibenskih bilježnika. Indricus de Indricis (1431.-1434.)" [Records of Šibenik’s notaries: Indricus de Indricis (1431-1434], Povijesni prilozi 41 (2013): 91-154.

${ }_{4}$ Nonetheless, it should be pointed out that Ser Indricus did not completely abandon his profession. As a former municipal chancellor and, unquestionably, a distinguished lawyer, Ser Indricus enjoyed an unrivalled reputation, which was the reason why many people, including a number of foreigners, employed his services as their legal representative or attorney. HR-SAZd-30, box 9, fol. 27'-28; box 11/1, vol. a, fol. 8'; box 11/1, vol. c, fol. 92-92'; box 11/3, fol. 96-96'; Dijecezanski arhiv u Šibeniku (hereafter: DAŠ), Diocese of Šibenik (hereafter: DŠ), vol. 263, fol. 27.

5 ... ser Indricum de Indrico de Venetiis habitatorem Sibenici generum predicti ser Stefani. HR-SAZd-30, box 11/1, vol. d., fol. 126 .

6 ... ser Indricus de Indrico de Venetiis ciuis et habitator Sibenici. DAŠ, DŠ, vol. 263, folder 2, fol. 107-107'.

7 ... vnam eius ser Stefani domum positam Sibenici in contrata sancti Gregorii, iuxta domum domini presbiteri Michaelis archidiaconi Scardone, iuxta viam publicam. HR-SAZd-30, box 11/1, vol. d, fol. 141.

8 DAŠ, DŠ, vol. 263, fol. 107- 107'.

9 The garden is mentioned only indirectly, as part of the description of the land boundaries, in a single sale and purchase document dated February 14, 1470. HR-SAZd-30, box 17/1, fol. 12', 65-65'.
} 
Owing to a number of preserved documents, especially sale and purchase agreements, as well as documents referring to the leasing of land, we are able to gain insight about the substantial collection of land properties acquired by Ser Indricus during his lifetime. Although, of course, it is not always possible to distinguish which of these properties were acquired by purchase, and which were received as dowry, it is well documented that Ser Indricus invested a part of his funds in purchasing such property. These included two vineyards, one the size of five gognaiorum (4237.5-4256.26 $\mathrm{m}^{2}$ ) in Donje Polje, in the area of St Lawrence, purchased in 1438 from a representative of Cvitan Bratković from Trogir, ${ }^{10}$ and the other of unknown size, also located in Donje Polje, in the area called Sadine, purchased in 1446 in a public auction of estates of the deceased Ser Juraj Bolković. ${ }^{11}$

Properties owned by Ser Indricus were, as a rule, located in the areas of Donje Polje or Gornje Polje, that is, the city district east of the river Krka. We can, thus, find his Donje Polje properties near the church of St Margaret, in Sadine and Morinj, ${ }^{12}$ the district of St Lawrence, ${ }^{13}$ and in Podgoričje, ${ }^{14}$ while his Gornje Polje properties were located near the village of Popel, ${ }^{15}$ in the village of Ogorilica, ${ }^{16}$ and in the area belonging to the village of Biranj (in Biljave and Pogovor, as well as in Ljubohin, an area near some natural wells). ${ }^{17}$ Ser Indricus also owned several estates that belonged to the village of Grebaštice (in the areas called Konoba, Pod Konobom, Brižine, Konačina, Stašine, and "next to the first pond belonging to the said village"), ${ }^{18}$ which were primarily acquired as dowry. These brought him one-third of young wine, oil, and other produce, which he traded further, as lease from the land holders, as the natural characteristics of these estates made them particularly suitable for viticulture. ${ }^{19}$

Other preserved notarial records, such as the money lending documents (mutu$u m$ ) and promissory notes, also testify to vigorous activity of Ser Indricus in loan trading. In the first instance, Ser Indricus features as a creditor of Ser Juraj Zgobi-

\footnotetext{
${ }^{10}$ HR-SAZd-30, box 3/b, fol. 100'-101.

${ }^{11}$ DAŠ, DŠ, vol. 263, fol. 181'.

${ }^{12}$ DAŠ, DŠ, vol. 263, fol. 181', 242'-243; HR-SAZd-30, box 9, fol. 100-100'; box 17/1, fol. 48'-49.

${ }^{13}$ HR-SAZd-30, box 3/b, fol. 100'-101.

${ }^{14}$ HR-SAZd-30, box 22, fol. 6-6.

${ }^{15}$ HR-SAZd-30, box 13 , fol. 176 .

${ }^{16}$ HR-SAZd-30, box 11/6, fol. 379'.

${ }_{17}$ DAŠ, DŠ, vol. 263, fol. 157-158, 201-201', 202; HR-SAZd-30, box 13, fol. 105.

${ }^{18}$ HR-SAZd-30, box 11/5, fol. 66, 75; box 11/6, fol. 124, 145, 158, 209; Ante Birin, Šibenski bilježnici: Bonmatej iz Verone (1449.-1451.) = Notai di Sibenico: Bonmatteo da Verona (Zagreb; Zadar; Šibenik: Croatian Institute of History; State Archives iz Zadar; State Archives in Šibenik, 2016), doc. 107, pp. 201-202; Ante Birin, Šibenski bilježnici: Juraj de Dominicis (1469.-1470.) = Notai di Sibenico: Giorgio de Dominicis (Zagreb; Zadar; Šibenik: Croatian Institute of History; State Archives iz Zadar; State Archives in Šibenik, 2016), 201-133, doc. 69.

${ }^{19}$ DAŠ, DŠ, vol. 263, fol. 157'-158; HR-SAZd-30, box 11/5, fol. 66; box 11/6, fol. 53, 209.
} 
ca, a nobleman from Šibenik, who in 1442 borrowed 100 Venetian libras of small denars (denarius parvus); of Jeronim, son of Jakov de Glozo from Belluno, who in 1442 borrowed 30 Venetian libras of small denars; $;^{20}$ of Matej Sitarčić, godfather to his child (compatris suo), who in 1444 borrowed 13 Venetian libras and 13 soldi of Venetian denars; ${ }^{21}$ of Ostoja, son of Vlatko Mancini from Šibenik, who in 1450 borrowed 19 Venetian libras of small denars; ${ }^{22}$ and of master artisans Radoš, Grgur, and Radoje Milinović, who in 1477 borrowed a certain amount of money, which unknown due to the damaged document. ${ }^{23}$ In the second instance, which concerns promissory notes, Ser Indricus acted as a creditor to Grubiša Pribislavić in 1448, who owed him 21 Venetian libras and 12 small soldi as a payment for one donkey and a repayment of his previous loan; ${ }^{24}$ and in 1450, as a creditor to Mihovil Radeljić, who owed him 80 Venetian libras of small denars for having received 40 modii (1716.8-2146 L) of wine. ${ }^{25}$

In addition to trading in agricultural products from his properties, Ser Indricus was involved in trade with other victuals, such as cheese, which he purchased from other merchants in large quantities and then resold. ${ }^{26}$

Yet another form of business activity in which Ser Indricus was involved was the lease of proceeds (locatio ad affictum) from individual church institutions and organisations, as well as from various municipal duties, in which, as a rule, several partners joined in and established a company (societas) in order to reduce the risk of high lease rates. Ser Indricus is documented in connection with such activity in the 1440 lease of proceeds from one tenth of the property belonging to the Bishop of Skradin, located in the Šibenik district, ${ }^{27}$ the 1442 lease of proceeds from the property of the monastery of St Nicholas de portu Sibenici, ${ }^{28}$ the 1446 lease of proceeds from the Split Archbishop's property in Bertolinšćina in the Sibenik district, ${ }^{29}$ and the 1442 lease of proceeds from the municipal duties of the island of Murter. ${ }^{30}$

Another capable and successful entrepreneur, who was at the very top of Šibenik's middle-class entrepreneurial elite and in many ways closer to the average members of that circle, was Ser Lovro Goniribić de Codignola. During the 1430s, Ser

\footnotetext{
${ }^{20}$ HR-SAZd-30, box 11/1, vol. c, fol. 95'; box 12, fol. 154'.

${ }^{21}$ HR-SAZd-30, box 11/4, fol. 162-162'.

${ }^{22}$ HR-SAZd-30, box 13, fol. 5'.

${ }^{23}$ HR-SAZd-30, box 11/7, vol. a, fol. 43'-44.

${ }^{24}$ HR-SAZd-30, box 11/6, fol. 178'.

${ }^{25}$ HR-SAZd-30, box 13, fol. 24'-25.

${ }^{26}$ HR-SAZd-30, box 111/1, vol. f, fol. 116'-117.

${ }^{27}$ DAŠ, DŠ, vol. 263, fol. 11'; HR-SAZd-30, box 12, fol. 28.

${ }^{28}$ HR-SAZd-30, box 11/1, vol. c, fol. 96-96'; vol. d, fol. 115-115'.

${ }^{29}$ DAŠ, DŠ, vol. 263, fol. 122'-123'.

${ }^{30}$ HR-SAZd-30, box 11/1, vol. d, fol. 148-148'.
} 
Lovro, son of Mihovil Goniribić and Cvita, ${ }^{31}$ rose so quickly on the social scale that at the end of the same decade, the notarial records regularly refer to him by the honourable title "Ser". ${ }^{32}$

He and his brother Disin, a master stonemason, were closely associated with another wealthy entrepreneur of that time, Ser Franjo Aldobrandi (ser Franciscus Aldobrandi de Figneldis de Florentia), a newcomer from Florence and a close associate of Ser Indricus. Ser Lovro, as the main leaseholder, and Ser Franjo belonged to a four-member company (societas) that leased the proceeds from the municipal mill duties (beginning from Christmas 1437), ${ }^{33}$ with the two of them simultaneously taking out a three-year lease of proceeds from the monastery of St Nicholas portus Sibenici (from the summer of 1442), ${ }^{34}$ as well as the lease of proceeds from the municipal duties of the island of Murter, as evident from the documents produced in 1443 and $1446 .{ }^{35}$

These business ties between Ser Franjo and the Goniribić family developed into family relations when, at the beginning of 1448, Ser Franjo married Disin's daughter Cvita, ${ }^{36}$ while in the meantime, probably before their marriage took place, Disin's son Grgur started to work for his future brother-in-law and stayed in his employment until the end of October $1452 .{ }^{37}$

${ }^{31}$ After the death of her husband Mihovil, Cvita married stonemason Andrija Raban from Zadar, now a resident of Šibenik, sometime before 1441. HR-SAZd-30, box 12, fol. 12-12'.

${ }^{32}$ The notarial records from the first half of the 1430s refer to him exclusively by his first name and surname, while the title Ser began to be regularly added and mentioned from 1438 onwards. Cf. Birin, "Spisi šibenskih bilježnika. Indricus de Indricis", doc. 2, pp. 103-104; doc. 7, p. 109; doc. 10, p. 112; HR-SAZd-30, box 3b, fol. 64-64' and 89-89'. The examples of Ser Indricus de Indrico and Ser Lovro Goniribić clearly support the conclusion that the usage of this title in late medieval private legal notarial documents cannot be automatically taken as defining the social position of a person, that is, as a mark of his noble status, as Zoran Ladić has indicated, concluding that "the increased social stratification was accompanied by the usage of titles like Ser and Domina, which were sometimes attached to members of the patrician class and occasionally to other prominent members of the society - wealthy artisans and merchants, medical professionals, artists and their wives, as well as other female members of their nuclear families, who belonged to the middle class or the groups of forenses and habitatores." Zoran Ladić, "O procesu demokratizacije u pisanju kasnosrednjovjekovnih privatno-pravnih bilježničkih isprava u istočno-jadranskim komunama" [Regarding the process of democratisation in the writing of late medieval private legal documents in the Eastern Adriatic communes], Zbornik odsjeka za povijesne znanosti Zavoda za povijesne i društvene znanosti Hrvatske akademije znanosti i umjetnosti 32 (2014): 44.

${ }_{33}$ The remaining two members of the company were Ser Mihovil Semjunić and Ser Jakov Nikolin. HRSAZd-30, box 11/1, vol. b, fol. 1'-2; vol. c, fol. 61'-62'.

${ }^{34}$ DAŠ, DŠ, vol. 263, I, fol. 14'-15. In 1446, the partners settled all mutual claims in connection with this lease and declared that they held no further claims among each other. DAŠ, DŠ, vol. 263, I, fol. 28-28'.

${ }^{35}$ HR-SAZd-30, box 11/1, vol. h, fol. 141'-142, 237'; DAŠ, DŠ, vol. 263, II, fol. 93'-94.

${ }^{36}$ The marital agreement dated April 29, 1447 sets forth that the marriage was to be concluded by mid-January of the following year, and reports that master Disin pledged to pay Ser Franjo, as Cvita's dowry, 500 small Venetian libras in property and money, as well as cede to him a vineyard the size of approximately three gognaios located in Donje Polje, in a place called Kameno Gumno (in loco vocato Camenogumeno), and a garden outside Šibenik. HR-SAZd-30, box 11/6, fol. 3'-4.

${ }^{37}$ Birin, Šibenski bilježnici: Bonmatej iz Verone, doc. 32, pp. 91-93. 
As far as is known, business relations within the family concern their 1441 company for the joint management of lime kiln on the island of Orut (present-day Zmajan), ${ }^{38}$ where they apparently also owned a quarry, ${ }^{39}$ and the 1452 company for the management of lime kiln on the island of Kruc. ${ }^{40}$ It is interesting to note that the business cooperation within the family continued with their children, Lovro's son Ante and Disin's son Grgur, who established a ten-year company for the management of a retail store one year later, in a joint venture with their cousin, Ser Franjo Aldobrandi. ${ }^{41}$ Thanks to the two later documents, it is possible to pin down the date of Ser Lovro's death sometime between April 26, 1452 and January 18,1453 , when he is mentioned as deceased. ${ }^{42}$

Although the number of properties owned by Ser Lovro Goniribić was not even close to that of Ser Indricus, it is recorded that he owned a house above the Dobrić Gate ${ }^{43}$ and a garden in Ugaršćica, outside, but near Šibenik. ${ }^{44}$ Doubtlessly, he invested a part of his funds into owning land, whereby only one of his land purchases from the 1430s is recorded, the 1431 land purchase in a public auction of the estates of the deceased stonemason Radoslav Stojslavić, by which Goniribić acquired a vineyard the size of three gognaiorum (2542.5-2553.75 $\mathrm{m}^{2}$ ) in Donje Polje at a price of 30 Venetian libras of small denars. ${ }^{45}$ Several more of his purchases were recorded during the next decade, when he in 1443 purchased one half of a country estate in Grebaštica from Stanislav Banić from the village of Orišje

\footnotetext{
${ }^{38}$ The transport of the produced lime and sand to Šibenik was entrusted to Jure Radašinić and Križan Mirković from Šibenik, who received 3 Venetian libras for each journey from the Goniribić brothers. HR-SAZd-30, box 12, fol. 53'-54.

${ }^{39}$ In a contract from 1447, master Disin pledged that the necessary material for the construction of several walls in two houses owned by Ser Šmun Ljubić, that is stone, would be obtained from his quarry on the island of Orut (in petraria sua insule Orut districtus Sibenici). HR-SAZd-30, box 11/5, fol. 3'-4. The stone from this quarry may also have been used when master Disin supplied the stone for the construction of a wall in the house owned by Dobrica, although the related contract from 1438 does not specify the location of the quarry in question. HR-SAZd-30, box 3b, fol. 48; Ivan Pederin, "Kamenarstvo i proizvodnja građevinskog materijala u Splitu i Šibeniku (XIV-XV. st.)” [Stone quarrying and the production of building material in Split and Šibenik $\left(14^{\text {th }}-15^{\text {th }}\right.$ c.) $]$, Klesarstvo i graditeljstvo 1 (1990), no. 2: 7-8; Sabine Florence Fabijanec, "Le rôle économique des îles croates médiévales", in: The 4th Mediterranean Maritime History Network Conference (Barcelona, 2018), 865.

${ }^{40}$... quamdam calcariam in insula Cruc Sibinici districtus. HR-SAZd-30, box 12, fol. 53'-54.

${ }^{41}$ HR-SAZd-30, box 13, fol. 140'-141.

${ }^{42}$ HR-SAZd-30, box 12, fol. 53'-54. We know that master Disin survived his brother Lovro for only several years, based on the 1458 mention of his (second) wife Cvita as a widow. HR-SAZd-30, box 13, fol. 76.

43 ... posita Sibenici super Dobrich. DAŠ, DŠ, vol. 263, I, fol. 50.

${ }^{44}$... positam in Vgarschiza extra et prope Sibenicum. Ser Lovro acquired this garden in 1446 by property exchange with Svila, widow of the late Dragiša Radmanić from Šibenik, to whom he gave twenty olive trees located on communal land in Veliki Kameničnik (Vršine) and fifteen Venetian libras of denars. DAŠ, DŠ, vol. 263, III, fol. 218'.

45 Birin, “Spisi šibenskih bilježnika. Indricus de Indricis”, doc. 2, pp. 103-104.
} 
and his sons, at a price of 6 Venetian libras of denars ${ }^{46}$ and a few years afterwards, when he in 1447 purchased one half of the bordering country estate in the same village from Martin Šumić from Grebaštica and his wife Košava, at a price of 20 Venetian libras of denars, ${ }^{47}$ and three land plots the size of three gognaiorum $\left(2542.5-2553.75 \mathrm{~m}^{2}\right)$ in Obrnja from master tanner Pavao Banjvarić, at a price of 30 small Venetian libras. ${ }^{48}$

Similarly to Ser Indricus and Ser Lovro, although to a considerably lesser extent (judging from the investigated sources), Goniribić was involved in loan business and food trade. Thus, we have found a record of a money loan to Katarina, widow of the late Ser Pavao Rančinić, in the amount of 200 Venetian libras dating from $1444,{ }^{49}$ but one can only speculate whether there was a loan behind the debt of Disman Slavogostić, collected in 1449, based on an arbitration award, by Ser Lovro for 25 ducats. ${ }^{50}$ Another document from that same year, which states that the brothers Pavao and Mihovil Radeljić, citizens of Šibenik, pledged to pay to Ser Lovro Goniribić, Ser Stjepan Draganić, and Ser Ilija Tolimerić 51 ducats (that is, one third of the amount to each of these creditors) as payment for four Venetian milliarum of "Morlach" cheese that they had purchased and received from them, proves that Ser Lovro was involved in cheese wholesale, while crediting the sale of cheese through promissory notes. ${ }^{51}$ In addition, based on the fact that he evidently kept a considerable number of livestock, it may be presumed that he himself was the producer of the cheese that he used in trade. We know of one herd of nearly 300 small livestock in his ownership, whose rearing was entrusted to Juraj Gojmilović from Grebaštica. ${ }^{52}$

\section{The entrepreneurial elite of late medieval Split}

Similarly to Šibenik, the middle-class elite in late medieval Split also based its social status on material wealth, that is, on personal pervasiveness and entrepreneurial ability. We will illustrate this interconnectedness between material wealth and the social status of individuals on the example of Split's pharmacist and spice merchant Ser Lapi, son of Zanobi (ser Lappus Zanobii, aromatarius, speciarius)..$^{53}$

\footnotetext{
${ }^{46}$ HR-SAZd-30, box 11/1, vol. e, fol. 91'-92.

${ }^{47}$ HR-SAZd-30, box 11/5, fol. 70-70'.

${ }^{48}$ HR-SAZd-30, box 11/5, fol. 75'-76.

${ }^{49}$ HR-SAZd-30, box 11/4, fol. 120-120'. Two years later, in 1446, the said Katarina paid him 94 Venetian libras and 5 soldi of denars for the settlement of all their mutual debts. DAŠ, DŠ, vol. 263, III, fol. 241'-242.

${ }^{50}$ Ser Lovro then transferred half of the mentioned amount to Ante Polišić from Šibenik, another creditor of Disman's. Birin, Šibenski bilježnici: Bonmatej iz Verone, doc. 39, pp. 103-104.

${ }^{51}$ Ibid., doc. 156, pp. 272-274.

${ }^{52}$ DAŠ, DŠ, vol. 263, II, fol. 58'.

${ }^{53}$ Medieval pharmacists were actually merchants of mixed goods who, among other things, specialised in the distribution of oriental spices and medicinal herbs. In addition to the terms speciarius and aro-
} 
He was an affluent member of the medieval commune's middle class and a fullfledged citizen, ${ }^{54}$ a distinguished member of Split's social elite during the first half of the $15^{\text {th }}$ century. This is most evident from his title "Ser," duly attached to his name by Split's notaries in their records. ${ }^{55}$

This entrepreneur based his social reputation primarily on wealth, which we can estimate only approximately, given that we dispose of a relatively small number of documents that mention land and other property in his ownership. Of all his properties, the preserved sources most often refer to Lapi's store (apotecha aromataria, statio), as the place where numerous notarial agreements (actum $)^{56}$ were prepared in his presence and for which he regularly acted as a witness. ${ }^{57}$ His store was located in Split's business centre, on the east side of St Lawrence's Square, most likely on the ground floor of a larger stone house (muralia),$^{58}$ where he presumably also lived ${ }^{59}$ with his wife Magdalena and their sons. ${ }^{60}$ Judging by the

matarius, medieval sources also use herbarius and apothecarius to describe their trade. Pharmacists first appeared in the Dalmatian communes in the $13^{\text {th }}$ century, most often as newcomers from Italy who sold medicinal preparations in Eastern Adriatic cities. Cf. Sabine Florence Fabijanec, "Mirodijari i veletrgovci začinima. Korištenje i promet začina na hrvatskoj jadranskoj obali u srednjem vijeku i početkom modernoga doba" [Spicers and Spice Merchants. Spice Usage and Spice Trade on the Croatian Adriatic Coast in the Middle Ages and Early Modern Era], in: Artisani et mercatores...: o obrtnicima i trgovcima na jadranskom prostoru / Artisani et mercatores...: Artisans and Merchants in the Adriatic Area, 8. istarski povijesni biennale / $8^{\text {th }}$ Istrian History Biennale, eds. Marija Mogorović Crljenko, Elena Uljančić (Poreč: Zavičajni muzej Poreštine; Sveučilište Jurja Dobrile u Puli; Državni Arhiv u Pazinu, 2019), 144, 152-155.

${ }^{54}$ HR-SAZd, Former Split Archives (hereafter: 579), box 11, 25/8, fol. 28-28.

${ }^{55}$ HR-SAZd-579, box 10/24, fol. 27-27'; box 11, 25/8, fol. 7, 28-28' Cf. n. 32 .

${ }^{56}$ HR-SAZd-579, box 8, 23/5, fol. 205'; box 9, 23/12, fol. 187'-188; box 10/24, fol. 27-27'; box 11, 25/8, fol. 29-29.

${ }^{57}$ HR-SAZd-579, box 10/24, fol. 27-27'; box 11, 25/8, fol. 1'-2, 7 .

${ }^{58}$ A document refers to Lapi's house as bordering on another property (proppe muraliam Lappi Zanobii) and, more importantly, as located in a street called cala mediante. HR-SAZd-579, box 9, 23/14, fol. 286. That was, in all probability, the main city street which divided the old town (ciuitas vetus) from the new town (ciuitas noua), and connected the northern gate (porta Pistorii) with the southern one (porta Marine); in one part, it ran along the east side of St Lawrence's Square. The $16^{\text {th }}$ century sources further refer to it as via tendente ad Portam Pisture and cale tendente ad marinam. Cf. Tomislav Raukar, Studije o Dalmaciji u srednjem vijeku [Studies on Dalmatia in the Middle Ages] (Split: Književni krug, 2007), 270.

${ }^{59}$ The houses owned by the commoners and residents of medieval Dalmatian communes were most often vertically divided into the ground floor, which was used for business and had a direct access from the street, and the upper floors, where the families lived, with a separate entrance via an external stone staircase. Cf. Cvito Fisković, "Romaničke kuće u Splitu i u Trogiru" [Romanesque houses in Split and Trogir], Starohrvatska prosvjeta 3 (1952), no. 2: 136. Josip Lučić, Obrti i usluge u Dubrovniku do početka 14. stoljeća [Crafts and services in Dubrovnik before the $14^{\text {th }}$ century] (Zagreb: Sveučilište u Zagrebu, Centar za povijesne znanosti, Odjel za hrvatsku povijest, 1979), 180; Marija Planić Lončarić, Planirana izgradnja na području Dubrovačke Republike [Planned constructions in the Dubrovnik Republic] (Zagreb: Centar za povijesne znanosti; Institut za povijest umjetnosti, 1980), 144-147; Nada Grujić, "Kuća 'savršenog trgovca' po Benediktu Kotruljeviću" [The house of a "perfect merchant" according to Benedikt Kotruljević], Dubrovnik: časopis za književnost i znanost 6 (n.s.) (1995), no. 4: 199; Irena Benyovsky, "Gospodarska topografija Trogira u srednjem vijeku" [Economic topography of Trogir in the Middle Ages], Povijesni prilozi 28 (2005): 29.

${ }^{60}$ We do not know much about Lapi's family life. His wife Magdalena is mentioned in a single document dating from 1455, as the widow of the already deceased Lapi, his heir, and the executor of his last 
location and the material used for its construction, their house was considered a very valuable property that few other citizens could afford.

As demonstrated by the given examples, wealthy entrepreneurs used to invest the surplus capital generated by their primary business in other forms of economic activity, above all in purchasing land, which they subsequently leased for farming. Lapi seems to have done the same, as evident from an agreement dating from 1448 , by which he leased a land plot in Smrdečac to Katica, wife of cobbler Miljen, in exchange for an annual rent of 15 Venetian libras (approximately 2.5 ducats). ${ }^{61}$ We reliably know that he also owned another land in one of the Split suburbs but as it is mentioned only briefly, as a land plot adjacent to another property in $1444,{ }^{62}$ we cannot accurately judge its use or profitability.

In fact, among the preserved documents of Split's notarial office, there are, indeed, only several business agreements of Lapi from which it is evident that he invested in economy, which is quite surprising given the established practice of increasing wealth by making new investments. It is indeed difficult to imagine that this respectable businessman "played it safe" by saving money in cash. Given his profession, he was dealing with foreign merchants who could supply him with oriental spices, import medicinal preparations from the East, and medicinal herbs that required a continental climate. ${ }^{63} \mathrm{He}$ may have established trading companies for that purpose and invested in maritime transport, as well as engaged in credit investment ${ }^{64}$ and currency exchange activities. However, surprisingly, no documents about such diversified business are preserved.

Nevertheless, the preserved sources still bear witness to Lapi's status as a respectable member of Split's society in the first half of the $15^{\text {th }}$ century. In the notarial registers, he is often referenced as the executor of his fellow citizens' last wills ${ }^{65}$ and

will (dona Magdalena, relicta ser Lappi aromatarii vt hereditaria et commisaria dicti ser Lappi), acting in nomine aliorum filiorum. HR-SAZd-579, box 11, 25/5, fol. 222-222'. The exact number of their sons cannot be concluded from the abovementioned notarial phrase.

${ }^{61}$ HR-SAZd-579, box 9, 23/14, fol. 257-257'. The ratio of Venetian ducat to libra in the $15^{\text {th }}$ century was approximately 1:6. Cf. Tonija Andrić, Život u srednjovjekovnom Splitu. Svakodnevnica obrtnika u 14. i 15. stoljeću [Life in medieval Split: The everyday life of artisans in the $14^{\text {th }}$ and $15^{\text {th }}$ centuries] (Zagreb; Split: Hrvatski institut za povijest; Filozofski fakultet Sveučilišta u Splitu, 2018), 48-49, n. 258.

${ }^{62}$... in suburbio ... proppe terram Lappi Zanobii... HR-SAZd-579, box 8, 23/3, fol. 139.

${ }^{63}$ Such business practice was previously documented in connection with other entrepreneurs of his profession. Cf. Fabijanec, "Mirodijari i veletrgovci začinima”, 152-158.

${ }^{64}$ Unlike other entrepreneurs who often engaged in granting cash loans, only one promissory note of Lapi's concerning a loan has been preserved. It was issued in 1445 to tanners Gojslav Bugarić and Pervinac Brajanović from Split in the amount of 65 Venetian libras for the purchase of raw materials used in crafts (pro coriis XIII bouinis). HR-SAZd-579, box 8, 23/8, fol. 369. With regard to the business practice of trading on the capital market, it is a surprise that Lapi did not engage in this aspect of economic activity more frequently.

${ }^{65}$ HR-SAZd-579, box 8, 23/4, fol. 160'; 23/8, fol. 352', 355'-356; box 9, 23/9, fol. 423; box 11, 25/8, fol. 28-28. 
a mediator in extrajudicial proceedings. ${ }^{66}$ In one document, he is also mentioned as the person who prepared a certain private legal document, ${ }^{67}$ which speaks volumes about his esteemed social status and, in particular, his level of education. We, therefore, maintain that the lack of written sources on Lapi's economic activity is not a result of his business lethargy, but rather a sheer coincidence resulting from the fragmentarily preserved notarial records.

Another prominent member of Split's middle-class entrepreneurial elite during the second half of the $15^{\text {th }}$ century was a newcomer from the Albanian city of Durres, Andrea Alessi (Andreas Alexii de Durachio), a stonemason and architect who first started his business activity in Dalmatia as a mere associate of the more famous Giorgio da Sebenico, only to soon become a completely independent and acknowledged master himself. Although his role in the construction and interior design of various sacral buildings in Split, ${ }^{68}$ and perhaps even public buildings ${ }^{69}$ and private noble palaces, ${ }^{70}$ has already been well researched, historians have not yet managed to fully chronicle his role in Split's economy. Our task here is, therefore, to introduce the less known Andrea Alessi - merchant, landlord, and real estate broker.

\footnotetext{
${ }^{66}$ In 1444, he is mentioned as an arbiter in a company owned by Split's nobleman (nobilis vir) Ser Antun, son of Ciprijan, in resolving a dispute between the shipbuilder Antun Hmelić and the commissioner Ivan, son of Luka Pervojević over the construction of a ship. HR-SAZd-579, box 8, 23/3, fol. 148, 149. This document also confirms that Lapi was a member of Split's social elite. Namely, it is rather difficult to imagine mediators in extrajudicial disputes as less known or less reputable members of the society, much less as members of a lower social class.

${ }^{67}$ It refers to the payment of a debt from 1444 that was registered per vnum cirographum [scriptum] manum Lappi Zanobii aromatarii in Spaleto. HR-SAZd-579, box 8, 23/5, fol. 235'. The document, regrettably, does not mention the reason why the promissory note for such a considerable amount (ducatos viginti auri) was prepared by Lapi himself and not by one of Split's public notaries.

${ }^{68}$ For example, he participated in some of the works during the renovation of the Split cathedral belfry: ... magister Andreas Alexi lapicida qui alias promissit facere certa laboreria cum magistro Nicolao Florentino ad campanille S. Doimi... HR-SAZd-579, box 15, 31/1, fol. 178'. He also,worked on the chapel of St Catherine within the Dominican church of the same name, and the chapel of St Jerome located on the nearby Marjan Hill. Cf. Cvito Fisković, Kruno Prijatelj, Albanski umjetnik Andrija Aleši u Splitu i u Rabu [The Albanian artist Andrea Alessi in Split and Rab] (Split: Slobodna Dalmacija, 1948), 46-51; Metod Hrg, Josip Kolanović, "Nova građa o Jurju Dalmatincu" [New sources on Giorgio da Sebenico], Arhivski vjesnik 17-18 (1975): 10; Duško Kečkemet, "Crkvica i eremitaža sv. Jere na Marjanu" [The church and hermitage of St Jerome on the Marjan Hill], Prilozi povijesti umjetnosti u Dalmaciji 11 (1959): 95-97.

${ }^{69}$ Duško Kečkemet, "Renesansna klesarsko-kiparska djela u Splitu" [Renaissance stonecarving and sculpture in Split], Prilozi povijesti umjetnosti u Dalmaciji 7 (1953): 62.

${ }^{70}$ Fisković, Prijatelj, Albanski umjetnik, 45-59; Milan Ivanišević, "Andrija Aleši u Splitu 1448. godine" [Andrea Alessi in Split in 1448], Kulturna baština 11-12 (1981): 15-23; Igor Fisković, "Neki vidovi umjetničkog djelovanja Jurja Dalmatinca u Šibeniku i u Splitu” [Some aspects of Giorgio da Sebenico's artistic activity in Šibenik and Split], Radovi Zavoda JAZU u Zadru 27-28 (1981): 139-140; Andrija Mutnjaković, Andrija Aleši [Andrea Alessi] (Zagreb: Krinen, 1998), 59-70; Emil Hilje, "Andrija Aleši i stambeno graditeljstvo u Splitu sredinom 15. stoljeća" [Andrea Alessi and Split's residential architecture], Radovi Instituta za povijest umjetnosti 29 (2005): 43-56.
} 
Although Andrea resided in Split from the mid- $15^{\text {th }}$ century, ${ }^{71}$ his business activity on the real estate market did not begin until the 1460s. He was, at that time, referred to as a ciuis et habitator Spaleti ${ }^{72}$ in the preserved agreements prepared by the notarial office, suggesting that he had already permanently settled here ${ }^{73}$ and owned his own property ${ }^{74}$ in which he probably lived. ${ }^{75}$ The same be inferred from an 1461 agreement, by which Andrea Alessi leased a stone house located in the centre of the city, ${ }^{76}$ which he obviously did not need as his own place of residence, to Ivan, son of the late Augustin. That Andrea's owned several properties is further corroborated by a later document from 1472, in which carpenter Antun Hmelić confirms that Andrea repaid him the debt he incurred by purchasing a house in the centre of the city, located near another house owned by him. ${ }^{77}$ Given the usual practice of leasing real estate, we can assume that Andrea purchased real estate in the most attractive part of Split in order to resell or lease it, thus accumulating surplus capital that he could invest in new properties. Such business practice is additionally confirmed by his trade in land plots.

Namely, in 1461, while granting the lease for the aforementioned house, Andrea also granted, by the same agreement, a four-year lease of two vineyards located in the vicinity of Split (Splitsko polje), ${ }^{78}$ which brought him 55 Venetian libras (more than 9 ducats) annually. ${ }^{79}$ Furthermore, he purchased a garden in the Split

\footnotetext{
${ }^{71}$ Ivanišević, "Andrija Aleši u Splitu", 16-17; Hilje, "Andrija Aleši”, 45-46.

${ }^{72}$ HR-SAZd-579, box 12, 27/1, fol. 43; box 13, 29/2, fol. 101; box 15, 32/1, fol. 80'-81.

${ }^{73}$ According to the provisions of the Split Statute, each newcomer had to reside in the city for at least six months prior to being formally and legally considered a citizen. Statut grada Splita. Splitsko srednjovjekovno pravo [The Statute of Split: Split's medieval law], ed. Antun Cvitanić, book NS, ch. 8 (Split: Književni krug, 1998), 810.

${ }^{74}$ The level of civil rights was directly related to the newcomer's material situation. It was, thus, necessary to own real estate within the commune to become a full-fledged citizens. However, the sale of real estate to foreigners first had to be approved by the majority in the patrician city council. Ibid., book 1 , ch. 21, 364; cf. Ante Birin, "Pravni položaj stranaca u statutima dalmatinskih komuna" [The legal position of foreigners in the statutes of Dalmatian communes], Zbornik odsjeka za povijesne znanosti Zavoda za povijesne i društvene znanosti Hrvatske akademije znanosti i umjetnosti 20 (2003): 84; Raukar, Studije o Dalmaciji, 45-46.

${ }^{75}$ This was probably a house in the neighbourhood of carpenter Antun Hmelić, which was mentioned as being owned by Andrea in documents dating as far back as 1455. Cf. Hilje, "Andrija Aleši," 52, n. 39.

${ }^{76}$...cessit et locauit ... vnam domum de muro coppis cohopertam, positam in terra veteri Spaleti... . HRSAZd-579, box 12, 27/1, fol. 43 .

77 ... pro resto ducatorum centum uiginti qui fuerint pro precio domus dicti magistri Antonii posite in ciuitate ueteri apud domum dicti magistri Andree... HR-SAZd-579, box 15, 31/1, fol. 164'.

${ }^{78}$ Item vnum terrenum vineatum, vretenorum duorum uel circa, situm apud S. Mariam Magdalenam in campo Spaleti... Item vnam vineam vretenorum vigintiquator uel circa, super terreno ser Petri et Iohannis Bubanich posito in campo Spaleti sub Dragouode... HR-SAZd-579, box 12, 27/1, fol. 43.

79 ... libras quinquagintaquinque paruorum omnibus anno quolibet usque ad complementum dictorum annorum quatuor. HR-SAZd-579, box 12, 27/1, fol. 43. That the rent was paid regularly can be inferred from the marginal notes on the notarial document.
} 
suburb for the purpose of leasing it for farming, probably sometime in $1466 .{ }^{80}$ At that time, he owned another plot in the vicinity of Split (Splitsko polje), at the site called Jame, used for wine-growing by the labourers who also owned the vines, ${ }^{81}$ but in 1474 he also purchased their vines ${ }^{82}$ and was thus able to dispose of the entire vineyard. Apart from that, in the 1470s Andrea was also very active in trade and had in the period of only 13 months completed several transactions on the real estate market. First, in June 1474 he exchanged one vineyard in Firule for a field in the Kamen area, ${ }^{83}$ and in March 1475 he purchased another vineyard in the Sucidar area, ${ }^{84}$ only to return it to the original owner on the same day, under unexplained circumstances, provided that it could not be sold to another person within the following three years. ${ }^{85}$ At that time he also owned another plot in the Mertojak area and another vineyard at the site of Longaro, as is evident from a document dated $1475 .{ }^{86} \mathrm{He}$ also purchased a tavern in the centre of the city that same year, ${ }^{87}$ thus adding a commercial building to his collection of Split real estate. In addition, he owned another land plot at the aforementioned site of Jame, yet another on the nearby Marjan Hill, as well as a land plot in Smrdečac, as is evident

${ }^{80}$... vnum ortum vretenum vnum uel circa, positum [in] burgo Spaleti proppe Staricantum, iuxta viam publicam a douobus lateribus et ortum done Ia[co]uiçe Xercouich et viam vicinalem et cetera. HRSAZd-579, box 13, 29/2, fol. 101.

${ }^{81}$ Labourers in Split, as in other Dalmatian communes, held the right of ownership over the crops that they had grown by their own labour and cultivated on the land owned by another person over a continuous period of 20 years. Cf. Statut grada Splita, book III, ch. 107, 566-568; Cf. Lujo Margetić, Srednjovjekovno hrvatsko pravo. Stvarna prava [Medieval Croatian law: Law of real property] (Zagreb; Rijeka; Čakovec: Pravni fakultet Sveučilišta u Zagrebu; Pravni fakultet Sveučilišta u Rijeci, 1983), 101; Lujo Margetić, Magdalena Apostolova Maršavelski, Hrvatsko srednjovjekovno pravo - vrela s komentarom [Croatian medieval law: Sources with a commentary] (Zagreb: Narodne novine, 1999), 129-131; Knjige nekretnina dubrovačke općine (13.-18. st.) [Books of real estate in the Dubrovnik commune], ed. Irena Benyovsky Latin and Danko Zelić (Zagreb; Dubrovnik; Zavod za povijesne znanosti HAZU u Dubrovniku, 2007), 26; Serđo Dokoza, Dinamika otočnog prostora. Društvena i gospodarska povijest Korčule $u$ razvijenom srednjem vijeku [The dynamics of island space: Social and economic history of Korčula in the High Middle Ages] (Split: Književni krug, 2009), 74.

82 Stanaç Dreuonich hoc Nicolaus Gregouich ... dedit et uendidit magistro Andree Alexii lapicide vnum vuretenum (!) cum dimidio vitum que pastinate fuerunt in vno terreno dicti magistri Andree in contrata uocata Iame... HR-SAZd-579, box 15, 31/1, fol. 292.

${ }^{83}$ Ser Mattheus cessit magistro Andree unum terrenum arratorium de proprio positum in confinibus Spaleti in loco uocato Pissani Camen ... ipse magister Andreas permutauit ipsi ser Mattheo unum terrenum vineatum posito in contrata Firuli... HR-SAZd-579, box 15, 32/1, fol. 20 '-21.

${ }^{84}$... pro remedio iure propriquietatis vnum terrenum cum vineam in contrata Sucidar... HR-SAZd-579, box $15,32 / 1$, fol. 89 .

${ }^{85}$... vnam vienam cum terreno in contrata Sucidar quam dictus Iohannes hodie de consensu dicti presbiteri Doimi uendidat ipsi magistro Andree habebit suos denarios ... hinc ad tres annos dicta vinea cum terreno libere renuntiauit. HR-SAZd-579, box 15, 32/1, fol. 89 .

${ }^{86}$... vnum terrenum, vretenorum circa octo positum in Mertougliach et vnam vineam positam a Longaro que bona sunt vendita ad incantum et de liberata Micllouso Gregoreuich et Radoslao Billoseuich. HRSAZd-579, box 15, 32/1, fol. 107.

${ }^{87}$... vnam canipam que est sub solario done Mariche, sororis ipsius Uiti et uxoris magistri Marini Milloseuich cimatoris... HR-SAZd-579, box 15, 32/1, fol. 90-90'. 
from his last will, in which he left these properties to the confraternity of the Holy Spirit, of which he was a member. ${ }^{88}$

All of the above indicates that Andrea Alessi was not interested in owning land merely to exploit it agriculturally, but also as a means of capital accumulation, whose surplus he shrewdly invested in new business on the market of residential real estate and land. The material security and financial liquidity thus achieved provided him with an unmatched social status and reputation among the social elite of that time. ${ }^{89}$

Master Antun Hmelić (magister Anthonius (C)hmelich) also belonged among the more capable members of Split's entrepreneurial elite in the $15^{\text {th }}$ century. He was a wealthy man and a full-fledged citizen, ${ }^{90}$ a versatile artisan working with wood: a carpenter, builder, and shipbuilder, ${ }^{91}$ a teacher of young apprentices, a wealthy landowner and an owner of several valuable properties, as well as a lending investor and financier.

The profitability of his chosen profession and his frequent business engagements provided Antun with a considerable property, which is evident from the sheer number of his real estate mentioned in the preserved documents. He owned as many as 4 houses, 3 of which were very valuable and located in the city centre, and a half of another house, which, although modest, had a garden and was located in the city suburb. He acquired his first luxury house with a stone staircase and the accompanying land in 1458, in exchange for a land on the Marjan Hill and another in Dragovode, with an additional payment of 40 Venetian libras to be made to the former owner over the following three years..$^{92} \mathrm{He}$ purchased his second house in 1472, for a substantial amount of 300 Venetian libras, by paying its seller, Ivan, son of Jakov from Cremona, 200 Venetian libras immediately, with the obligation to settle the difference within a year. ${ }^{93}$ Antun's third house was also

${ }^{88}$ Irena Benyovsky, Tatjana Buklijaš, "Bratovština i hospital sv. Duha u Splitu u srednjem i ranom novom vijeku" [The confraternity and hospital of the Holy Spirit in Split during the medieval and early modern periods], in Raukarov zbornik: zbornik u čast Tomislava Raukara, editor Neven Budak (Zagreb: Filozofski fakultet Sveučilišta u Zagrebu, Odsjek za povijest, 2005), 637-638.

${ }^{89}$ Andrea's social status and reputation are not evident only from his business engagements and his income, but also from the fact that he had business relations with the wealthy patricians and citizens of Split, who often appointed him their attorney in affairs regarding their property or a witness to their business transactions. See e.g. HR-SAZd-579, box 15, 31/1, fol. 165, 178'; 32/1, fol. 50', 80, 80'-81, 90, 92, 113.

${ }^{90}$ HR-SAZd-579, box 11, 25/ 8, fol. 28-28'; box 15, 31/1, fol. 151-151'.

${ }_{91}$ In medieval Split, craftsmen who specialised in woodwork could advance only slowly, so they simultaneously worked as marangones or carpentarii, as calafati, and even as murarii. It is precisely these titles that were used when referencing Antun Hmelić in the notarial documents. See e.g. HR-SAZd-579, box 8, 23/3, fol. 148'; 23/8, foil 371-371'; box 12, 26/1, fol. 5'; 27/3, fol. 116-116'.

92 ... ipse Vuchus promissit dare ipsi Anthonium libras XL ${ }^{\text {ta }}$ paruorum ... vt libras 15 ad festum S. Michaelis, proxime futuro et alias libras 15 usque ad alius festum S. Michaelis inde venturo et X libras pro reliquo ad tertius festum S. Michaelis. HR-SAZd-579, box 12, 26/1, fol. 19.

${ }_{93}$ HR-SAZd-579, box 15, 31/ 1, fol. 165, 166. This means that Antun disposed of a large amount of cash and planned to achieve high profit in the next year, which is, in itself, a sufficient evidence of his wealth. 
located in the very heart of the city, but as it is mentioned only briefly in the sources, as bordering on another property, ${ }^{94}$ we can only speculate about its value and purpose. Finally, he owned a half of a house with garden on a church land in the suburb. ${ }^{95}$ Although he probably used it for leasing, he was able to resell it should a good opportunity arise, the practice which proved not to be unfamiliar to Antun. Aside from the residential real estate, Antun Hmelić, like other entrepreneurs of his time, invested in land, as a means of additional accumulation of capital and the most visible sign of social status. As far as we can conclude from the available data, he owned quite a substantial amount of land for that time, with a total area of at least 15 vreteno,${ }^{96}$ in addition to several vineyards, excluding the land on which they were grown. ${ }^{97}$ Although he sold his first vineyard in $1445,{ }^{98}$ he purchased two other vineyards in 1454 , their total area amounting to 14 vreteno. ${ }^{99} \mathrm{But}$ apparently his most lucrative investment properties were located on the nearby Marjan Hill, where he owned several agricultural plots. In 1446, he purchased a land as much as 24 ducats worth, located in the immediate vicinity of one of his other plots, from barber Damjan. ${ }^{100}$ In 1447, he leased his third plot on the Marjan Hill to Radoslava Bogdanić, ${ }^{101}$ and in 1458 he acquired his fourth plot on the Marjan Hill, which he later exchanged for the aforementioned house. ${ }^{102}$ Investing in land for the purpose of leasing proved to be a wise business practice, which steadily supplemented Antun's revenue from his primary profession.

But Antun Hmelić was not merely an artisan, a capable real estate trader, and a wealthy landlord; he also invested in other forms of economic activity that would ultimately bring him profit. He engaged in loan trade, lending money to

94 ... in terra veteri Spaleti, iuxta viam publicam, iuxta magistram Anthonium Hmelich... HR-SAZd-579, box $12,27 / 1$, fol. 43 .

${ }_{95}$... medietatem unius domus cum medietate orti positorum in burgo Spalati ad Gusternam, super terreno monialium S. Benedicti de Spalato, cuius domus et orti altera medietas est Antonii, sui filii et Lucie, sue filie. HR-SAZd-579, box 15, 32/1, fol. 18'.

${ }_{96}$ Approximately $12,783.135 \mathrm{~m}^{2}$ or 1.2 ha. One Split vreteno equalled $852.209 \mathrm{~m}^{2}$ or 0.08 ha. Cf. Marija Zaninović-Rumora, "Stare mjere Splita od 15. do 19. stoljeća" [Old measurements in Split $\left(15^{\text {th }}-19^{\text {th }}\right.$ c.)], Zbornik odsjeka za povijesne znanosti Zavoda za povijesne i društvene znanosti Hrvatske akademije znanosti i umjetnosti u Zadru 52 (2010): 185-186. Nevertheless, Antun's land may have been even larger. Namely, some of his plots are only briefly mentioned in certain documents, as bordering on other properties, and thus do not specify the area. See e.g. HR-SAZd-579, box 8, 23/8, fol. 384'.

${ }^{97}$ See n. 81 .

98 ... dedit et vendidit ... vnam eius vineam et vites arbores quam fructiferas quas habuit cum iure predicto super terra arhiepiscopatus... HR-SAZd-579, box 8, 23/5, fol. 238.

${ }^{99}$ HR-SAZd-579, box 11, 25/8, fol. 28-28.

${ }^{100}$... posita in Mergnano, prope terram Antonii Hmelich marangoni... HR-SAZd-579, box 8, 23/ 8, fol. 384 .

${ }^{101}$... dedit et concessit ad laborandum et pastinandum ... vnam eius terram positam in Mergnano... HRSAZd-579, box 9, 23/11, fol. 52-52'.

${ }^{102}$ HR-SAZd-579, box 12, 26/1, fol. 19. 
prominent members of Split's social elite, ${ }^{103}$ while at the same time increasing and further investing his income from the church land that he managed. ${ }^{104}$ Since he also wisely managed the property of others, his fellow citizens often appointed him their attorney in affairs regarding their own properties ${ }^{105}$ the executor of their testaments, ${ }^{106}$ and a witness to their business transactions and the notarisation of their documents, ${ }^{107}$ a mediator in extrajudicial proceedings, ${ }^{108}$ and even as a guardian to orphans and minors. ${ }^{109}$ Furthermore, he also mainained four artisan apprentices $^{110}$ and two additional workers ${ }^{111}$ for at least two years, which did not seem to constitute a great expense for such a wealthy master. We should conclude by saying that he also generated high income from his primary profession ${ }^{112}$ and then further invested the capital thus acquired in real estate and other business. His material wealth, thus, ultimately earned him an impeccable social status and gained him admittance to Split's social elite.

\footnotetext{
${ }^{103}$ For example, in 1446, he lent 40 Venetian libras and 40 soldi to the Archbishop of Split, don Marko, son of Mislen for the purchase of stone, as can be observed from the preserved debt repayment certificate issued in 1448. HR-SAZd-579, box 9, 23/12, fol. 192'. That same year, he also issued a debt repayment certificate in the amount of 20 small Venetian libras to Ser Dujam Musičić, who had owed this amount to him as dowry for his wife Katarina. HR-SAZd-579, box 9, 23/12, fol. 151'. He also lent money to Andrea Alessi, to whom he sold a house for a large sum of 120 ducats in 1472, as documented by the debt repayment certificate. HR-SAZd-579, box 15, 31/1, fol. 164'. He used that money to purchase another luxury house in the city centre from the previously mentioned Ivan, son of Jakov from Cremona. See n. 93.

${ }^{104}$ Thus, in 1449 he leased the proceeds from the land held by the Benedictine monastery of St Stephen sub pinis for a substantial amount of 50 ducats, which he paid to the procurators of the abovementioned abbey in two instalments over a period of six months. HR-SAZd-579, box 9, 23/16, fol. 377'-378. Although the notary does not state the reason for leasing the aforementioned proceeds, we can assume that Antun's intention was to continue leasing or reselling them for profit.

${ }^{105}$ HR-SAZd-579, box 15, 31/1, fol. 130, 151-151', 242-242'; 32/1, fol. 34-34'.

${ }^{106}$ HR-SAZd-579, box 15, 31/1, fol. 130.

${ }^{107}$ HR-SAZd-579, box 12, 27/1, fol. 8-8'; box 15, 31/1, fol. 215, 215-215', 218', 289; 32/1, fol. 47.

${ }^{108}$ HR-SAZd-579, box 8, 23/3, fol..149; box 15, 31/1, fol. 33', 37', 188, 188'-189.

${ }^{109} \mathrm{He}$ was, for example, a guardian of Margarita, daughter of the late Jakov Nestašić, whom he, by a premarital agreement, married off to goldsmith Andrija in 1474; and he also concluded a dowry agreement on behalf of a certain Katarina with her prospective husband Šimun Radojević from Split in 1475. HR-SAZd-579, box 15, 32/1, fol. 49, 102-102'.

${ }^{110}$ HR-SAZd-579, box 8, 23/5, fol. 242'; 23/8, fol. 371-371'; box 9, 23/12, fol. 158'; 23/14, fol. 276.

${ }^{111}$ Such additional workers are referred to by their profession in the sources, but without the title magister. HR-SAZd-579, box 9, 23/13, fol. 201'-202; 23/16, fol. 376. Cf. Tonija Andrić, "Položaj obrtničkih naučnika i pomoćne radne snage u Splitu sredinom 15. stoljeća" [The position of artisan apprentices and auxiliary labourers in Split (mid-15 ${ }^{\text {th }}$ c.) ], Zbornik odsjeka za povijesne znanosti Zavoda za povijesne $i$ društvene znanosti Hrvatske akademije znanosti i umjetnosti 29 (2011): 142.

${ }^{112}$ Thus, he charged certain work (certa laboreria) on Split's church of the Holy Cross 146 Venetian libras (approximately 25 ducats), and received additional 30 small Venetian libras (approximately 5 ducats) for certain lesser shipbuilding work that he performed in partnership with a man called Ivan Pervojević. In 1474, he carved a base of an altarpiece for the church of Our Lady of the Belfry (vna anchona facta super altare ecclesie S. Marie de Campanili), thus earning 10 more Venetian libras (approximately 1.5 ducats) for this simple job. HR-SAZd-579, box 8, 23/3, fol. 149; box 12, 26/1, fol. 35; box 15, 32/1, fol. 46. Other artisans with less profitable professions, such as tailors or cobblers, could only dream of such an income.
} 


\section{Conclusion}

The creation of entrepreneurial climate in the cities of Venetian Dalmatia during the $15^{\text {th }}$ century created ample business opportunities and allowed the more capable and business-oriented craftsmen and merchants not only to acquire great wealth, but also to secure a prominent place among the social elite of that time. Even though our paper presents only a few examples that illustrate such interrelations of economic activity and social rise, due to constraints imposed on it by focusing on a specific geographical area, the presented examples illustrate that all entrepreneurs mentioned here achieved their economic and social advancement in an almost identical way, regardless of whether they lived and worked in Šibenik or Split.

Ser Indricus de Indrico, a newcomer from Venice, relatively quickly discovered the opportunities offered by Šibenik's economic system and exchanged his former position in the municipal administration for a significantly more profitable real estate and loan investment business, whilst affirming his social status among Šibenik's elite by marrying a daughter of a prominent citizen. A similar example of private and economic advancement among the Šibenik entrepreneurial elite is Ser Lovro Goniribić, who in the same manner strengthened his business relations with trading companies by establishing family ties with his business partners.

The same entrepreneurial models and patterns of social behaviour can be simultaneously observed among the social elite of late medieval Split. A newcomer to Split, Andrea Alessi from Durrës, likewise supplemented his income from stone masonry with real estate deals, while Antun Hmelić, an esteemed carpenter, based his wealth on land revenues rather than his craft. Finally, the example of pharmacist Ser Lapi, son of Zanobi, further confirms the previously demonstrated strong interconnection between business success and social affirmation.

All the above instances lead us to conclude that successful and capable Dalmatian entrepreneurs rapidly developed recognisable business models, which brought them substantial profit and, as a consequence, the guarantee of social advancement, by seizing the opportunities within the Venetian economic system in Dalmatia. These businessmen continually increased their capital, generated from their primary business activity, by wise investments in the capital market and the local real estate, while associating themselves with successful economic agents in the society, engaged in related economic activities, allowed them to expand their business by making safe investments in their joint ventures and lucrative trading. Notarial records allow us to trace the social ascent of these entrepreneurs along with their business successes, as indicated by the use of simple legal formulations and notarial expressions Ser and Civis when referring to them. The wealthy entrepreneurs, thus, eventually became respectable members of their communities and prominent members of the Dalmatian social elite. 
126 Tonija Andrić, Ante Birin, The Middle-Class Entrepreneurial Elite in Šibenik and ...

\section{APPENDIX}

Hogenberg; Braun, Sibinium, Ptolomeo Sicum vulgo Sibenicho Dalmatie opp: 1576. g., papir 17,8 x 24,5 cm, inv. br. 2551

Fototeka Muzej grada Šibenika

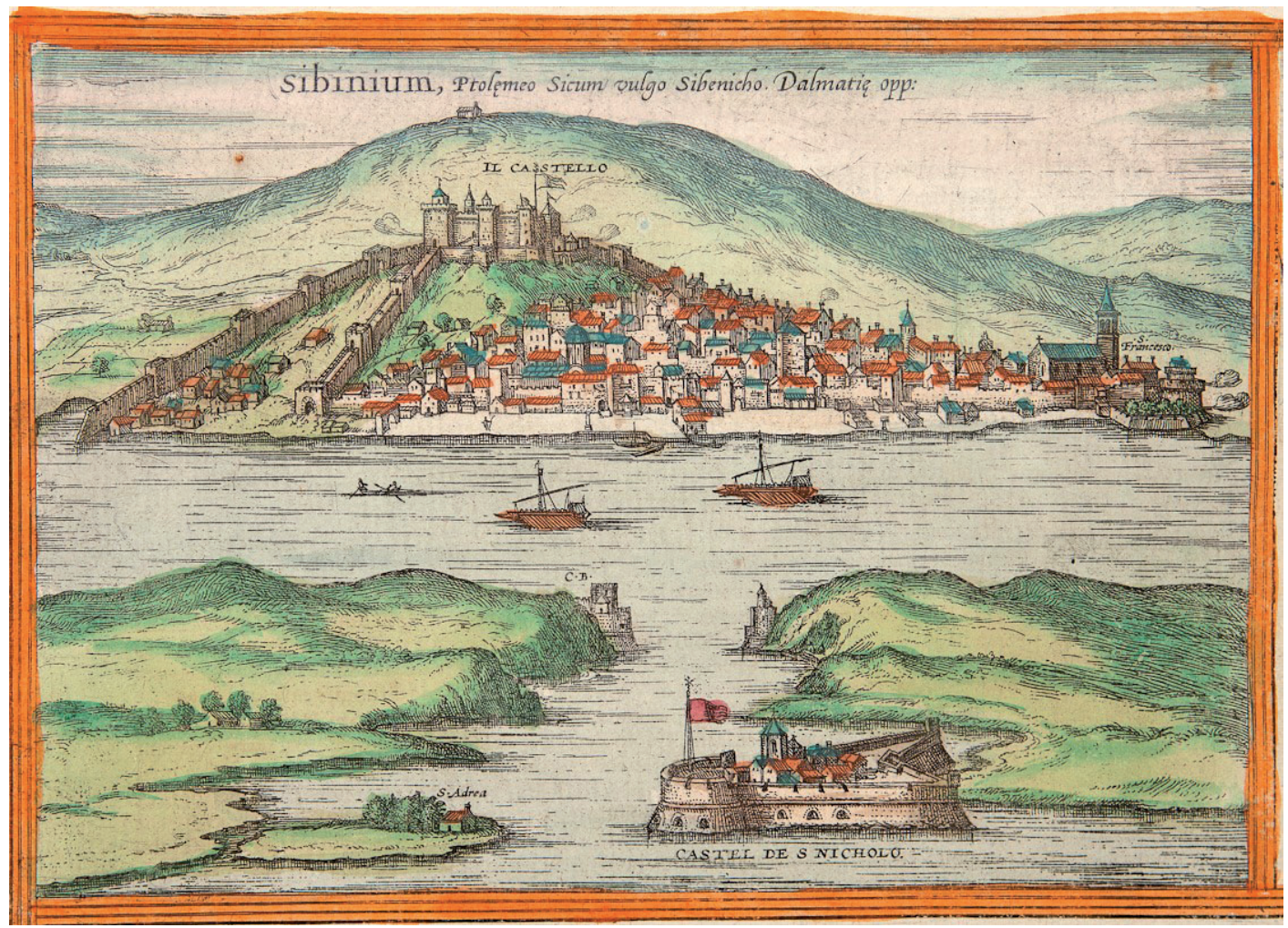




\section{Archival and published sources}

Croatia - Diocesan Archive in Šibenik - sv. 263

Croatia - State Archive in Zadar - fond Stari splitski arhiv, kutije 8-15

Croatia - State Archive in Zadar - fond Bilježnici Šibenika, kutije 3-17.

Benyovsky Latin, Irena; Zelić, Danko, prir. Knjige nekretnina dubrovačke općine (13.-18. st.) [Books of real estate in the Dubrovnik commune]. Zagreb; Dubrovnik: HAZU, Zavod za povijesne znanosti u Dubrovniku, 2007.

Cvitanić, Antun. Statut grada Splita. Splitsko srednjovjekovno pravo [The Statute of Split: Split’s medieval law]. Split: Književni krug, 1998.

\section{Literature}

Andrić, Tonija. "Položaj obrtničkih naučnika i pomoćne radne snage u Splitu sredinom 15. stoljeća" [The position of artisan apprentices and auxiliary labourers in Split (mid-15th century)]. Zbornik Odsjeka za povijesne znanosti Zavoda za povijesne i društvene znanosti HAZU 29 (2011): 127-147.

Andrić, Tonija. Život u srednjovjekovnom Splitu. Svakodnevnica obrtnika u 14. i 15. stoljeću [Life in medieval Split: The everyday life of artisans in the 14th and 15th centuries]. Zagreb; Split: Hrvatski institut za povijest; Filozofski fakultet u Splitu, 2018.

Barbarić, Josip; Kolanović, Josip. Šibenski diplomatarij [Šibenik’s diplomata]. Šibenik: Muzej grada Šibenika, 1986.

Benyovsky Latin, Irena. "Gospodarska topografija Trogira u srednjem vijeku" [Economic topography of Trogir in the Middle Ages]. Povijesni prilozi 28 (2005): 23-44.

Benyovsky Latin, Irena; Buklijaš, Tatjana. "Bratovština i hospital sv. Duha u Splitu u srednjem i ranom novom vijeku" [The confraternity and hospital of the Holy Spirit in Split during the medieval and early modern periods]. U: Raukarov zbornik: zbornik u čast Tomislava Raukara, urednio Neven Budak, 625-657. Zagreb: Filozofski fakultet, Odsjek za povijest, 2005.

Birin, Ante. "Pravni položaj stranaca u statutima dalmatinskih komuna" [The legal position of foreigners in the statutes of Dalmatian communes]. Zbornik Odsjeka za povijesne znanosti Zavoda za povijesne i društvene znanosti HAZU 20 (2003): 59-94.

Birin, Ante. "Spisi šibenskih bilježnika. Indricus de Indricis (1431.-1434.)" [Records of Šibenik's notaries: Indricus de Indricis (1431-1434]. Povijesni prilozi 41 (2013): 91-154. 
Birin, Ante. Šibenski bilježnici: Bonmatej iz Verone (1449.-1451.) = Notai di Sibenico: Bonmatteo da Verona. Zagreb; Zadar; Šibenik: Hrvatski institut za povijest; Zadar: Državni arhiv u Zadru; Državni arhiv u Šibeniku, 2016.

Birin, Ante. Šibenski bilježnici: Juraj de Dominicis (1469.-1470.) = Notai di Sibenico: Giorgio de Dominicis. Zagreb; Zadar; Šibenik: Hrvatski institut za povijest; Zadar: Državni arhiv u Zadru; Državni arhiv u Šibeniku, 2018. .

Dokoza, Serđo. Dinamika otočnog prostora. Društvena i gospodarska povijest Korčule u razvijenom srednjem vijeku [The dynamics of island space: Social and economic history of Korčula in the High Middle Ages]. Split: Književni krug, 2009.

Fabijanec, Sabine Florence. "Mirodijari i veletrgovci začinima. Korištenje i promet začina na hrvatskoj jadranskoj obali u srednjem vijeku i početkom modernoga doba" [Spicers and Spice Merchants. Spice Usage and Spice Trade on the Croatian Adriatic Coast in the Middle Ages and Early Modern Era]. In: Artisani et mercatores...: o obrtnicima i trgovcima na jadranskom prostoru / Artisani et mercatores...: Artisans and Merchants in the Adriatic Area, 8. istarski povijesni biennale / 8th Istrian History Biennale, eds. Marija Mogorović Crljenko, Elena Uljančić, 144-163. Poreč: Zavičajni muzej Poreštine; Sveučilište Jurja Dobrile u Puli; Državni Arhiv u Pazinu, 2019.

Fabijanec, Sabine Florance. "Le rôle économique des îles croates médiévales". U: The 4th Mediterranean Maritime History Network Conference, 857-876. Barcelona, 2018.

Fisković, Cvito. "Romaničke kuće u Splitu i u Trogiru" [Romanesque houses in Split and Trogir]. Starohrvatska prosvjeta 3 (Zagreb: 1952), sv. 2: 129-178.

Fisković, Cvito; Prijatelj, Kruno. Albanski umjetnik Andrija Aleši u Splitu i u Rabu [The Albanian artist Andrea Alessi in Split and Rab]. Split: Novinsko izdavačko poduzeće Slobodna Dalmacija, 1948.

Fisković, Igor. "Neki vidovi umjetničkog djelovanja Jurja Dalmatinca u Šibeniku i u Splitu" [Some aspects of Giorgio da Sebenico's artistic activity in Šibenik and Split]. Radovi Zavoda JAZU u Zadru 27-28 (1981): 107-177.

Grujić, Nada. "Kuća 'savršenog trgovca' po Benediktu Kotruljeviću" [The house of a "perfect merchant" according to Benedikt Kotruljević]. Dubrovnik: časopis za književnost $i$ znanost VI (nova ser.) (1995), br 4: 198-212.

Hilje, Emil. "Andrija Aleši i stambeno graditeljstvo u Splitu sredinom 15. stoljeća" [Andrea Alessi and Split's residential architecture]. Radovi Instituta za povijest umjetnosti 29 (2005): 43-56.

Hrg, Metod; Kolanović, Josip. "Nova građa o Jurju Dalmatincu" [New sources on Giorgio da Sebenico]. Arhivski vjesnik 17-18 (1975): 7-25. 
Ivanišević, Milan. "Andrija Aleši u Splitu 1448. godine" [Andrea Alessi in Split in 1448]. Kulturna baština 11-12 (1981): 14-23.

Ladić, Zoran. "O procesu demokratizacije u pisanju kasnosrednjovjekovnih privatno-pravnih bilježničkih isprava u istočno-jadranskim komunama” [Regarding the process of democratisation in the writing of late medieval private legal documents in the Eastern Adriatic communes]. Zbornik Odsjeka za povijesne znanosti Zavoda za povijesne i društvene znanosti Hrvatske akademije znanosti i umjetnost $i$ 32 (2014): 39-66.

Margetić, Lujo. Srednjovjekovno hrvatsko pravo. Stvarna prava [Medieval Croatian law: Law of real property]. Zagreb; Rijeka; Čakovec: Pravni fakultet u Zagrebu; Pravni fakultet u Rijeci, 1983.

Margetić, Lujo; Maršavelski Apostolova, Magdalena. Hrvatsko srednjovjekovno pravo - vrela s komentarom [Croatian medieval law: Sources with a commentary]. Zagreb: Narodne novine, 1999.

Kečkemet, Duško. "Crkvica i eremitaža sv. Jere na Marjanu" [The church and hermitage of St Jerome on the Marjan Hill]. Prilozi povijesti umjetnosti u Dalmaciji 11 (1959): 92-105.

Kečkemet, Duško. "Renesansna klesarsko-kiparska djela u Splitu" [Renaissance stonecarving and sculpture in Split]. Prilozi povijesti umjetnosti u Dalmaciji 7 (1953): 59-82.

Lučić, Josip. Obrti i usluge u Dubrovniku do početka 14. stoljeća [Crafts and services in Dubrovnik before the 14th century]. Zagreb: Sveučilište, Institut za hrvatsku povijest, Odjel za hrvatsku povijest, 1979.

Mutnjaković, Andrija. Andrija Aleši [Andrea Alessi]. Zagreb: Krinen, 1998.

Pederin, Ivan. "Kamenarstvo i proizvodnja građevinskog materijala u Splitu i Šibeniku (XIV-XV. st.)" [Stone quarrying and the production of building material in Split and Šibenik (14th-15th c.)]. Klesarstvo i graditeljstvo 1 (1990), br. 2.

Planić Lončarić, Marija. Planirana izgradnja na području Dubrovačke Republike [Planned constructions in the Dubrovnik Republic]. Zagreb: Centar za povijesne znanosti; Odjel za povijest umjetnosti, 1980.

Raukar, Tomislav. Studije o Dalmaciji u srednjem vijeku [Studies on Dalmatia in the Middle Ages]. Split: Književni krig, 2007.

Zaninović-Rumora, Marija. "Stare mjere Splita od 15. do 19. stoljeća" [Old measurements in Split (15th-19th c.)]. Radovi Zavoda za povijesne znanosti HAZU u Zadru 52 (2010): 173-188. 
Tonija Andrić*

Ante Birin**

\section{Poduzetnička elita građanskog staleža u Šibeniku i Splitu 15. stoljeća}

\section{Sažetak}

Temeljem sačuvane građe šibenske i splitske notarske kancelarije, ovaj tekst proučava poslovnu elitu kasnosrednjovjekovnog Šibenika i Splita na primjerima nekih istaknutih poduzetnika. Tekst posebno razmatra suodnos poslovnog etabliranja i društvenog uspona istaknutih šibenskih građana Indrika de Indrico i Lovre Goniribića te uglednih pripadnika splitske komune Lapija Zanobijevog, Andrije Alešija i Antuna Hmelića. Na ovim primjerima uočava se gotovo posve identičan modus operandi predstavljenih građana u njihovu socijalnom i privrednom djelovanju.

Ključne riječi: Šibenik, Split, poduzetništvo, kasni srednji vijek, notarski spisi, Indrik de Indrico, Lovro Goniribić, Lapi Zanobijev, Andrija Aleši, Antun Hmelić

\footnotetext{
* Tonija Andrić, Odsjek za povijest, Filozofski fakultet u Splitu, Sveučilište u Splitu, Poljička 35, 21000 Split, Republika Hrvatska, E-mail adresa: tonija@ffst.hr

** Ante Birin, Hrvatski institut za povijest, Opatička 10, 10000 Zagreb, Republika Hrvatska, E-mail adresa: ante.birin@gmail.com
} 